\title{
Model Pendugaan Evaporasi dari Suhu Udara dan Kelembaban Udara Menggunakan Metode Regresi Linier Berganda di Kota Pontianak Eka Mey Jesiania*, Apriansyah ${ }^{\mathrm{b}}$, Riza Adriat ${ }^{\mathrm{c}}$
}

\author{
aProdi Fisika, bProdi Ilmu Kelautan, cProdi Geofisika, FMIPA Universitas Tanjungpura \\ Jalan Prof. Dr. Hadari Nawawi, Pontianak, Indonesia \\ * Email : apriansyahhakim@yahoo.com
}

\begin{abstract}
Abstrak
Penelitian ini bertujuan untuk memperoleh persamaan model pendugaan evaporasi berdasarkan data suhu udara dan kelembaban udara di Kota Pontianak tahun 2006 - 2017. Analisa korelasi dan pembentukan model evaporasi dengan metode regresi linier berganda menenggunakan data suhu udara dan kelembaban udara dari stasiun klimatologi Siantan dan data evaporasi yang diperoleh dari situs resmi ECMWF. Kemudian model ini diuji kesesuaiannya dengan menghitung nilai $\mathrm{R}^{2}$, $\mathrm{r}$ dan error absolutnya. Hasil penelitian ini menunjukkan bahwa korelasi antara suhu udara dan kelembaban udara dengan evaporasi di Kota Pontianak sangat erat yang berarti evaporasi dapat diprediksi dengan data suhu udara dan kelembaban udara. Persamaan model evaporasi yang dihasilkan adalah adalah $E v=$ $151,2982+15,19076 \mathrm{~T}-4,65079 R H$. Model ini dapat memprediksi evaporasi yang terjadi di Kota Pontianak dengan error absolut $1,9 \%$.
\end{abstract}

Kata Kunci : Evaporasi, Suhu Udara, Kelembaban Udara

\section{Latar Belakang}

Evaporasi adalah suatu proses berubahnya air menjadi uap air dari perairan terbuka, tanah dan batuan lainnya. Proses evaporasi sangat dipengaruhi oleh perbedaan tekanan uap, suhu udara, angin, kualitas air dan permukaan bidang evaporasi [1]. Pengukuran besarnya evaporasi dapat dilakukan dengan berbagai macam teknik, mulai dari pengukuran langsung dengan panci evaporasi atau perhitungan dengan berbagai metode dan gabungan keduanya [2].

Berkembangnya ilmu pengetahuan dan teknologi dewasa ini mendorong berkembangnya berbagai macam metode pendugaan evaporasi yang menggunakan data klimatologi tertentu (tekanan udara, radiasi matahari, kelembaban udara dan suhu udara) seperti metode Langbein, Thorntwaite, Turc, persamaan Rohwer, persamaan Orstom dan metode Penman [3]. Berbagai kemudahan dan kepraktisan dalam menaksir besarnya evaporasi diberikan metode-metode tersebut. Namun, metode tersebut harus diuji dan disesuaikan dengan lokasi lokal wilayah penelitian karena persamaan empiris yang terkandung dalam rumus mengandung besaran yang diperoleh di setiap negara dimana metode tersebut dikembangkan.

Dalam penelitian ini diterapkan metode regresi linear berganda yang bertujuan untuk mengestimasi nilai evaporasi berdasarkan data suhu udara dan kelembaban udara rata-rata dalam interval waktu bulanan di Kota Pontianak. Diharapkan penelitian ini dapat menjadi referensi pendukung dalam pemahaman proses evaporasi di Kota Pontianak yang disebabkan oleh parameter suhu dan kelembaban udara.

\section{Metodologi}

2.1 Data

Data yang digunakan terdiri dari data suhu udara dan kelembaban udara selama 10 tahun (2007-2016) yang diperoleh dari Stasiun Klimatologi Siantan dan data evaporasi model yang diunduh dari link berikut https://www.ecmwf.int.

\subsection{Pengolahan Data}

Pengolahan data dilakukan melalui proses sebagai berikut:

1. Perhitungan suhu udara rata-rata bulanan dan kelembaban udara rata-rata bulanan

Data rata-rata suhu dan kelembaban udara dihitung dengan persamaan (1) dan (2).

$$
\begin{aligned}
& \bar{T}=\frac{\Sigma \mathrm{T}}{N} \\
& \overline{R H}=\frac{\Sigma \mathrm{RH}}{N} \\
& \text { Keterangan } \\
& \mathrm{T} \quad=\text { Suhu Udara }\left({ }^{\circ} \mathrm{C}\right) \\
& \mathrm{RH}=\text { Kelembaban Udara }(\%) \\
& \mathrm{N} \quad=\text { Jumlah data }
\end{aligned}
$$

2. Penggunaan metode regresi linear berganda

Secara umum model regresi linier berganda yang digunakan adalah sebagai berikut:

$$
\mathrm{EV}=\mathrm{a}+b_{1} \mathrm{~T}+b_{2} \mathrm{RH}
$$


keterangan:

$\mathrm{EV}=\operatorname{Evaporasi}(\mathrm{mm})$

$\mathrm{T}=$ Suhu udara $\left({ }^{0} \mathrm{c}\right)=\mathrm{x}$

$\mathrm{R}=$ Kelembaban udara (\%)=y

a $=$ Konstanta (nilai Y' apabila $x_{1}$. $x_{2} \ldots . . x_{n}=0$ )

$\mathrm{b}=$ Koefisien regresi (nilai peningkatan ataupun penurunan)

Untuk nilai konstanta b menggunakan persamaan sebagai berikut:

$b_{1}=\frac{\left[\left(\sum T^{2} X \sum T \times E V\right)-\left(\sum R H \times E V X \sum T \times R H\right)\right]}{\left[\begin{array}{ll}\left(\sum T^{2} X \sum R H^{2}\right)-\left(\sum T X \quad R H\right) 2\end{array}\right]}$

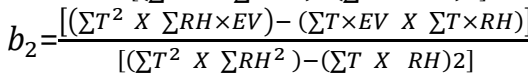

Untuk nilai persamaan a menggunakan rumus persamaan sebagai berikut:

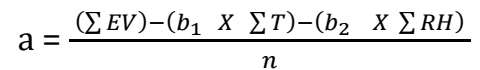

\subsection{Analisis Data}

Dalam subbab analisis data digunakan analisis korelasi untuk mendapatkan hubungan antara Suhu Udara dan vaporasi; Kelembaban udara dan evaporasi. Tingkat korelasi yang dihitung dengan persamaan (6) di bawah ini:

$r_{x y}=\frac{n\left(\sum T\right)-\sum X \sum Y}{\sqrt{n\left(\sum X^{2}\right)-\left(\sum X\right)^{2}} \sqrt{n\left(\sum Y^{2}\right)-\left(\sum Y\right)^{2}}}$

Hasil perhitungan selanjutnya diinterpretasikan menggunakan Tabel 1 untuk mengetahui korelasi antara parameter suhu dan kelembaban udara terhadap evaporasi.

Tabel 1. Hubungan Koefisien Korelasi dan Interpretasi

\begin{tabular}{c|c}
\hline Koefisien & Interpretasi \\
Korelasi (r) & Torelasi \\
\hline 0 & Tidak ada \\
$0-0,25$ & Sangat lemah \\
$0,25-0.50$ & cukup \\
$0,50-0,75$ & kuat \\
$0,75-0,99$ & sangat kuat \\
1 & Sempurna \\
\hline
\end{tabular}

Sumber: Tjasyono [4]

Selanjutnya juga dilakukan perbandingan antara hasil perhitungan Evaporasi dengan metode regresi linier berganda dan hasil kalkulasi model dari situs ECMWF. Proses perbandingan antara kedua hasil model ini dilakukan dengan melihat error absolut $\left(\mathrm{e}_{\mathrm{a}}\right)$ yang dihitung dengan persamaan (7) berikut :

$e_{a}=\left|\frac{\text { Evaporas }_{E C M W F}-\text { Evaporasi }_{\text {Regresi }}}{\text { Evaporasi }_{E C M W F}}\right| x 100$

\section{Hasil dan Pembahasan}

\subsection{Pola Suhu Udara dan Kelembaban Udara Bulanan}

Berdasarkan data suhu udara bulanan dan kelembaban udara yang telah didapat, dihasilkan rata-rata suhu udara dan kelembaban udara dari tahu 2007 s.d 2016 seperti yang dapat dilihat pada Gambar 1

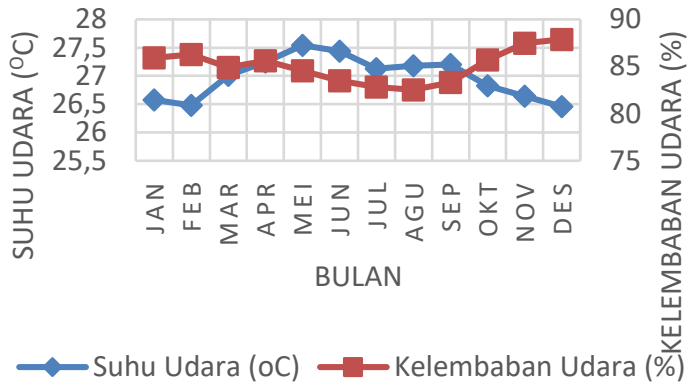

Gambar 1. Grafik rata-rata suhu udara (merah) dan kelembaban udara (biru) selama tahun 2006-2017 di Kota Pontianak

Rata-rata suhu bulanan tertinggi di Kota Pontianak terjadi pada bulan Mei yaitu $27,54^{\circ} \mathrm{C}$ dan rataa-rata suhu bulanan terendah terjadi pada bulan Desember yaitu $26,45^{\circ} \mathrm{C}$ dengan rata-rata sebesar $26,97^{\circ} \mathrm{C}$ (Gambar 1). Suhu udara diartikan sebagai ukuran panas/ dinginnya udara di suatu tempat pada waktu tertentu. Suhu udara lebih banyak dipengaruhi oleh banyak atau sedikitnya panas matahari yang diterima oleh bumi. Secara umum, tingginya suhu udara di Kota Pontianak disebabkan oleh letak Kota Pontianak yang berada di sekitar garis katulistiwa (lintang 0) sehingga mempengaruhi terhadap lama penyinaran (radiasi) matahari. Intensitas radiasi matahari maksimum terjadi di bulan Juli dan Agustus, hal ini disebabkan karena pada bulan Juli dan Agustus merupakan periode puncak musim kemarau sehingga pemanasan matahari ke permukaan bumi paling optimal. Intensitas radiasi matahari minimum terjadi di bulan Desember dan Januari karena bulan ini merupakan puncak musim hujan dimana pertumbuhan awan-awan konvektif sangat banyak sehingga menghalangi radiasi matahari ke permukaan bumi. Jika dilihat pada Gambar 1 diketahui bahwa suhu udara memiliki nilai di atas nilai rata-rata bulannyanya pada bulanbulan kering yakni Maret, April, Juni, Juli, Agutus, September. Suhu udara lebih rendah dari nilai rata-rata bulanannya terjadi pada bulan-bulan basah yakni Oktober, November, Desember, Januari dan Februari. [5]

Sementara Kelembaban udara bulanan tertinggi di Kota Pontianak terjadi pada Bulan Desember yaitu $87,88 \%$. dan rata-rata bulanan kelembaban udara terendah yang terjadi pada bulan Agustus sebesar 82,52\% dengan rata-rata sebesar 85,04\%. Kelembaban udara adalah jumlah kandungan uap air yang ada di udara. Penyinaran yang dilakukan oleh matahari juga 
menjadi salah satu hal yang mempengaruhi kelembaban suatu udara. Penyinaran yang tinggi akan menurunkan kelembaban yang tinggi. Hal ini tidak lepas dari kandungan uap air pada suatu udara. Penyinaran matahari akan menghilangkan kandungan uap air sehingga akan berdampak pada menurunnya tingkat kelembaban udara. Untuk kota Pontianak, kelembaban udara sangat erat kaitannya dengan periode puncak musim kemarau dan hujan. Pada bulan Juli dan Agustus adalah puncak musim kemarau sementara bulan Desember dan Januari adalah puncak musim hujan. Semakin banyak curah hujannya semakin tinggi kelembaban udaranta. Hal ini yang menyebabkan kelembaban udara tertinggi dan terendah terjadi pada bulan Desember dan bulan Agustus.

Dari Gambar 1 juga dapat ditarik beberapa analisa yakni suhu pada bulan Januari hingga Mei yang meningkat mengakibatkan kelembaban udara di periode tersebut menurun. Hal sebaliknya terjadi pada suhu udara bulan Agustus hingga Desember yang menurun dan dikuti dengan peningkatan kelembaban udara di bulan-bulan tersebut. Hal ini mengindikasikan bahwa terdapat keterkaitan antara suhu udara dan kelembaban udara di Kota Pontianak.

\subsection{Hubungan antara suhu udara dan evaporasi}

Variasi suhu udara rata-rata bulanan selama 10 tahun terhadap evaporasi bulanan di Kota Pontianak dapat dilihat pada Gambar 1. Secara umum, grafik pola variasi evaporasi bulanan dan suhu rata-rata bulanan hampir sama. Saat suhu udara tinggi diikuti dengan meningkatnya evaporasi, Ketika suhu udara relatif rendah, evaporasi pun relative rendah. Dengan demikian, laju evaporasi di Kota Pontianak akan sebanding dengan perbedaan suhu udara.
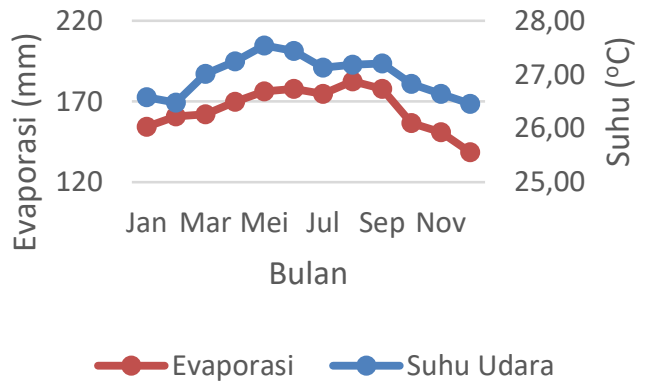

Gambar 2. Grafik rata-rata suhu udara bulanan (biru) dan evaporasi bulanan (merah)

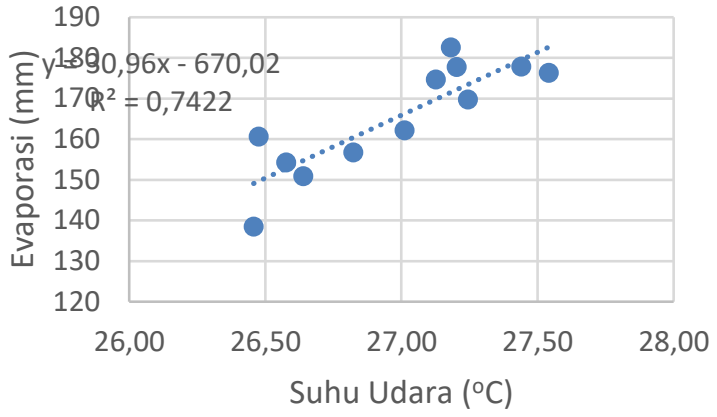

Gambar 3. Plot hubungan suhu udara dan evaporasi

Dari Gambar (3) dapat diketahui bahwa nili koefisien determinansi $\left(\mathrm{R}^{2}\right)$ pada grafik plot sebesar 0,7422. Angka ini mengandung arti bahwa 74,22\% variasi dari evaporasi di Kota Pontanak dapat dijelaskan dengan variasi suhu udara rata-ratanya dan sisanya dapat diterangkan dari parameter lainnya. Sementara nilai koefisien korelasi ( $\mathrm{r}$ ) menunjukkan angka 0,86 berarti suhu udara rata-rata bulanan dan proses evaporasi di Kota Pontianak memiliki hubungan yang sangat kuat.

\subsection{Hubungan antara kelembaban udara dan evaporasi}

Dalam Gambar (4), dapat dilihat variasi kelembaban udara rata-rata bulanan dari tahun 2006-2017 terhadap evaporasi bulanan dalam intwrval waktu yang sama di Kota Pontianak. Secara umum, grafik pola kelembaban udara memiliki hubungan yang berbanding terbalik dengan grafik evaporasi. Jika kelembaban udara rendah maka evaporasi tinggi. Begitu juga sebaliknya jika kelembaban udara menurun maka evaporasinya meningkat. Ini terlihat jelas dalam data kelembaban udara bulan Januari hingga Agustus yang turun sementara evaporasinya meningkat. Begitu juga di bulan Agustus hingga Desember, kelembaban udara naik dan laju evaporasinya turun. Dengan demikian laju evaporasi di Kota Pontianak berbanding terbalik dengan perbedaan kelembaban udara.

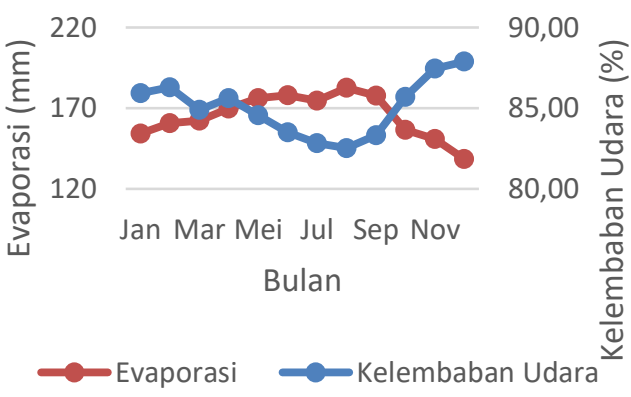

Gambar 4. Grafik rata-rata kelembaban udara bulanan (biru) dan evaporasi bulanan (merah) 


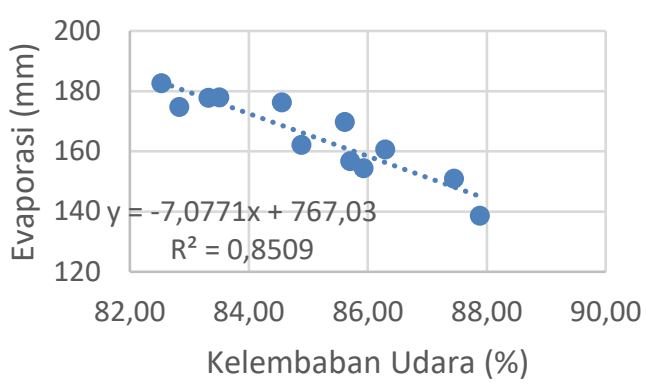

Gambar 5. Plot hubungan kelembaban udara

Nilai koefisien determinansi $\left(\mathrm{R}^{2}\right)$ antara kelembaban udara dan evaporasi di Kota Pontianak menunjukkan angka 0,8509 (Gambar 5). Ini mengandung arti bahwa $85,09 \%$ variasi dari evaporasi bulanan di Kota Pontianak dapat diterangkan oleh variasi kelembaban udara rata-ratanya sementara sisanya dapat diterangkan dari parameter lainnya. Nilai koefisien korelasi (r) menunjukkan angka -0,92. Hal ini berarti bahwa proses evaporasi di Kota Pontianak memiliki hubungan yang sangat kuat dengan parameter kelembaban udara yang terukur di lokasi tersebut. Tanda (-) pada koefisien korelasi menunjukkan bahwa hubungan antara evaporasi dan kelembaban udara berbanding terbalik.

\subsection{Perbandingan evaporasi hasil regresi linier berganda dan evaporasi dari data ECMWF}

Pada penelitian ini model evaporasi dikembangkan dengan menggunakan parameter suhu udara dan kelembaban udara sebagai prediktornya, Metode yang digunakan adalah regresi linier berganda. Model evaporasi perhitungan dengan regresi linier berganda ini kemudian diuji kesesuaiannya dengan uji statistic yaitu nilai koefisien determinansi $\left(\mathrm{R}^{2}\right)$ dan error absolut. Sementara koefisien korelasi (r) yang digunakan sebagai acuan untuk menentukan dapat tidaknya model pendugaan evaporasi digunakan pada penelitian ini sebesar 0,50 yang merupakan batas bawah yang menunjukkan hubungan erat yang kuat antara dua variabel.

Persamaan matematika dari model evaporasi yang dihitung dari data suhu udara dan kelembaban udara di Kota Pontianak adalah $\quad E v=151,2982+15,19076 T-$ $4,65079 R H$. Model ini selanjutnya diuji kesesuaiannya dengan menjari nilai $\mathrm{R}^{2}$ dan error absolut. Koefisien hasil pengujian model evaporasi dengan regresi linier berganda di Kota Pontianak sebesar 0,9136 (Gambar 6). Sehingga nilai koefisien korelasi nya (r) sebesar 0,95. Nilai tersebut menunjukkan bahwa keeratan hubungan antara evaporasi dari data ECMWF di Kota Pontianak dengan evaporasi model regresi linier berganda dari suhu udara dan kelembaban udara yang sangat kuat dan perbedaan nilai antara keduanya tidak terlalu besar. Model evaporasi ini memiliki tingkat kesalahan kurang dari 2\% yang ditunjukkan oleh nilai error absolut sebesar 0,019 atau 1,90\%. Nilai kesalahan tersebut model evaporasi hasil regresi cukup teliti memprediksi evaporasi di Kota Pontianak.

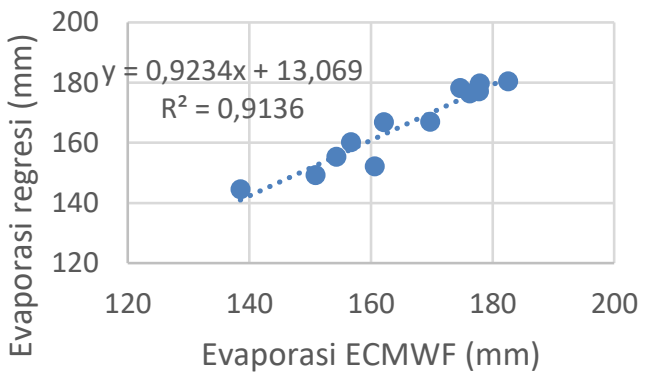

Gambar 6. Scatter Plot Evaporasi dari data

ECMWF dan Evaporasi hasil model regresi Grafik evaporasi dari data ECMWF dan evaporasi model pada Gambar 7 yang berdekatan dan memiliki pola yang sama menunjukkan koherensi yang berdekatan antara keduanya. Ini artinya model regresi linier berganda yang memanfaatkan data suhu udara dan kelembaban udara dapat digunakan untuk menghitung evaporasi di Kota Pontianak.

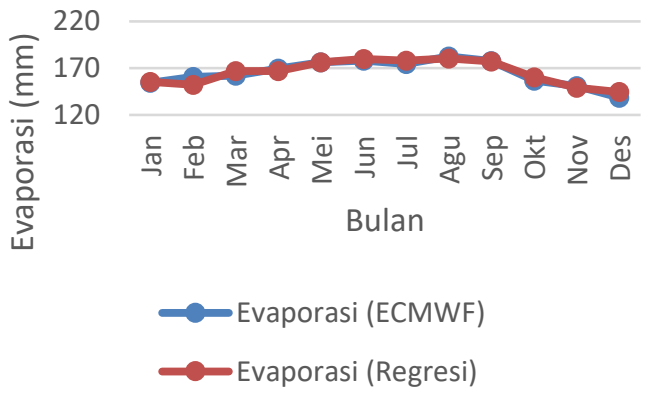

Gambar 7. Grafik kemiripan Evaporasi data ECMWF dan Evaporasi Model di Kota Pontianak 


\section{Kesimpulan}

Korelasi suhu udara dengan evaporasi dan korelasi kelembaban udara dengan evaporasi berdasarkan data hasil pengukuran suhu udara rata-rata bulanan dan kelembaban udara ratarata bulanan dan evaporasi dari ECMWF di Kota Pontianak dinyatakan sangat erat dengan nilai koefisien korelasi ( $r$ ) masing-masing sebesar 0,86 dan $-0,92$.

Dengan demikian, evaporasi dapat dihitung dengan menggunakan data suhu udara dan kelembaban udara di Kota Pontianak. Persamaan model pendugaan evaporasi memanfaatkan metode regresi linier berganda yang sesuai dengan kondisi iklim di Kota Pontianak adalah $E v=151,2982+$ $15,19076 T-4,65079 R H$. Persamaan model ini dapat diterapkan di Kota Pontianak dengan koefisien korelasi $0,95 \%$ dan error absolut $1,9 \%$.

\section{Daftar Pustaka}

[1] Aldrian, E. 2008. Meteorologi Laut: Pusat Penelitian dan Pengembangan Badan Metereologi Dan Geofisika. Jakarta.

[2] Kirono, D.G.C., 2001, Modul Matakuliah Hidrometeorologi, Yogjakarta, Fakultas Geografi UGM]

[3] Singh, R.V., 1989, Hydrologic System, Vol II, New Jersey: Prentice-Hall Inc

[4] Tjasyono, B.H.K. 2004. Klimatologi. Bandung: ITB.

[5] Kurniawan, N. 2012. Profil Kota Pontianak, Pontianak: Inspirita.

[6] Lakitan, B. 1994. Dasar-dasar klimatologi. Jakarta: PT. Raja Grafindo Persada

[7] Soemarto. 1995. Hidrologi Teknik. Jakarta: Erlangga.

[8]Tjasyono, B.H.K. 2004. Klimatologi. Bandung: ITB.

[9] Young Seung Chung, H. S., 2010. The Solar Eclipse and Associated Atmospheric Variations Observed In South Korea on 22 July2009.https://www.ncbi.nlm.nih.gov/pub med/20700380, (2 November 2017).

[10] Grandis, H., Pengantar Pemodelan Inversi Geofisika, Himpunan Ahli Geofisika Indonesia (HAGI), CV. Bhumi Printing. 